
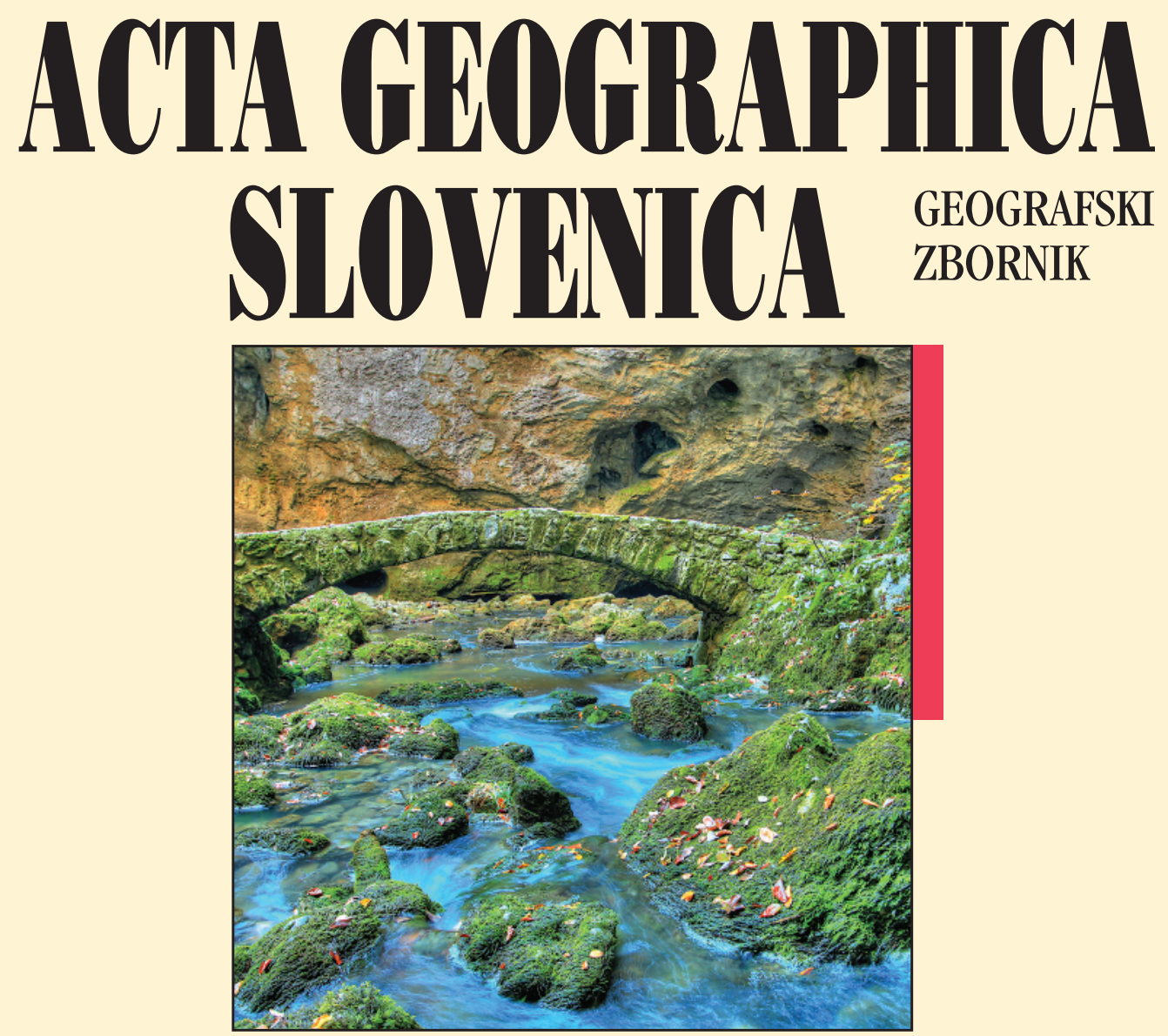


\section{ACTA GEOGRAPHICA SLOVENICA GEOGRAFSKI ZBORNIK \\ 59-1 • 2019}

\section{Contents}

Maja KOCJANČIČ, Tomislav POPIT, Timotej VERBOVŠEK

Gravitational sliding of the carbonate megablocks in the Vipava Valley, SW Slovenia

Małgorzata KIJOWSKA-STRUGAŁA, Anna BUCAŁA-HRABIA

Flood types in a mountain catchment: the Ochotnica River, Poland

Irena MOCANU, Bianca MITRICĂ, Mihaela PERSU

Socio-economic impact of photovoltaic park: The Giurgiu county rural area, Romania

Andrej GOSAR

The size of the area affected by earthquake induced rockfalls: Comparison of the 1998 Krn Mountains (NW Slovenia) earthquake $\left(M_{w} 5.6\right)$ with worldwide data

Matej GABROVEC, Peter KUMER

Land-use changes in Slovenia from the Franciscean Cadaster until today

Mojca FOŠKI

Using the parcel shape index to determine arable land division types

Mateja FERK, Matej LIPAR, Andrej ŠMUC, Russell N. DRYSDALE, Jian ZHAO

Chronology of heterogeneous deposits in the side entrance of Postojna Cave, Slovenia

\section{Special issue - Green creative environments}

Jani KOZINA, Saša POLJAK ISTENIČ, Blaž KOMAC

Green creative environments: Contribution to sustainable urban

and regional development

Saša POLJAK ISTENIČ

Participatory urbanism: creative interventions for sustainable development

Jani KOZINA, Nick CLIFTON

City-region or urban-rural framework: what matters more in understanding

the residential location of the creative class?

Matjaž URŠIČ, Kazushi TAMANO

The importance of green amenities for small creative actors in Tokyo:

Comparing natural and sociocultural spatial attraction characteristics

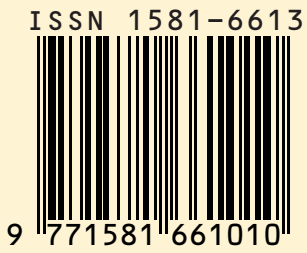




\section{ACTA GEOGRAPHICA SLOVENICA}

$59-1$

2019

ISSN: 1581-6613

COBISS: 124775936

UDC/UDK: 91

(C) 2019, ZRC SAZU, Geografski inštitut Antona Melika

International editorial board/mednarodni uredniški odbor: David Bole (Slovenia), Michael Bründl (Switzerland), Rok Ciglič (Slovenia), Matej Gabrovec (Slovenia), Matjaž Geršič (Slovenia), Peter Jordan (Austria), Drago Kladnik (Slovenia), Blaž Komac (Slovenia), Andrej Kranjc (Slovenia), Dénes Lóczy (Hungary), Simon McCharty (United Kingdom), Slobodan Marković (Serbia), Janez Nared (Slovenia), Drago Perko (Slovenia), Marjan Ravbar (Slovenia), Nika Razpotnik Visković (Slovenia), Aleš Smrekar (Slovenia), Annett Steinführer (Germany), Mimi Urbanc (Slovenia), Matija Zorn (Slovenia)

Editor-in-Chief/glavni urednik: Blaž Komac; blaz@zrc-sazu.si

Executive editor/odgovorni urednik: Drago Perko; drago@zrc-sazu.si

Chief editor for physical geography/glavni urednik za fizično geografijo: Matija Zorn; matija.zorn@zrc-sazu.si Chief editor for human geography/glavna urednica za humano geografijo: Mimi Urbanc; mimi@zrc-sazu.si

Chief editor for regional geography/glavni urednik za regionalno geografijo: Drago Kladnik; drago.kladnik@zrc-sazu.si

Chief editor for spatial planning/glavni urednik za regionalno planiranje: Janez Nared; janez.nared@zrc-sazu.si

Chief editor for rural geography/glavna urednica za geografijo podeželja: Nika Razpotnik Visković; nika.razpotnik@zrc-sazu.si Chief editor for urban geography/glavni urednik za urbano geografijo: David Bole; david.bole@zrc-sazu.si

Chief editor for geographic information systems/glavni urednik za geografske informacijske sisteme: Rok Ciglič; rok.ciglic@zrc-sazu.si

Chief editor for environmental protection/glavni urednik za varstvo okolja: Aleš Smrekar; ales.smrekar@zrc-sazu.si

Editorial assistant/uredniški pomočnik: Matjaž Geršič; matjaz.gersic@zrc-sazu.si

Issued by/izdajatelj: Geografski inštitut Antona Melika ZRC SAZU

Published by/založnik: Založba ZRC

Co-published by/sozaložnik: Slovenska akademija znanosti in umetnosti

Address/Naslov: Geografski inštitut Antona Melika ZRC SAZU, Gosposka ulica 13, SI - 1000 Ljubljana, Slovenija

The papers are available on-line/prispevki so dostopni na medmrežju: http://ags.zrc-sazu.si (ISSN: 1581-8314)

Ordering/naročanje: Založba ZRC, Novi trg 2, p. p. 306, SI - 1001 Ljubljana, Slovenija; zalozba@zrc-sazu.si

Annual subscription/letna naročnina: $20 €$ for individuals/za posameznike, $28 €$ for institutions/za ustanove.

Single issue/cena posamezne številke: $12,50 €$ for individuals/za posameznike, $16 €$ for institutions/za ustanove.

Cartography/kartografija: Geografski inštitut Antona Melika ZRC SAZU

Translations/prevodi: DEKS, d. o. o.

DTP/prelom: SYNCOMP, d. o. o.

Printed by/tiskarna: Tiskarna Present, d. o. o.

Print run/naklada: 350 copies/izvodov

The journal is subsidized by the Slovenian Research Agency and is issued in the framework of the Geography of Slovenia core research programme (P6-0101)/revija izhaja s podporo Javne agencije za raziskovalno dejavnost Republike Slovenije in nastaja v okviru raziskovalnega programa Geografija Slovenije (P6-0101).

The journal is indexed also in/revija je vključena tudi v: SCIE - Science Citation Index Expanded, Scopus, JCR - Journal Citation Report/Science Edition, ERIH PLUS, GEOBASE Journals, Current geographical publications, EBSCOhost, Geoscience e-Journals, Georef, FRANCIS, SJR (SCImago Journal \& Country Rank), OCLC WorldCat, Google scholar, and CrossRef

Oblikovanje/Design by: Matjaž Vipotnik.

Front cover photography: Stone bridge over the Rak River on the outskirts of the Rakov Škocjan polje, which is otherwise known for its beautiful natural bridges (photograph: Matej Lipar).

Fotografija na naslovnici: Kamniti most čez reko Rak na obrobju kraškega polja Rakov Škocjan, ki je sicer bolj znano po čudovitih naravnih mostovih (fotografija: Matej Lipar). 


\section{CHRONOLOGY OF HETEROGENEOUS DEPOSITS IN THE SIDE ENTRANCE OF POSTOJNA CAVE, SLOVENIA}

Mateja Ferk, Matej Lipar, Andrej Šmuc, Russell N. Drysdale, Jian Zhao

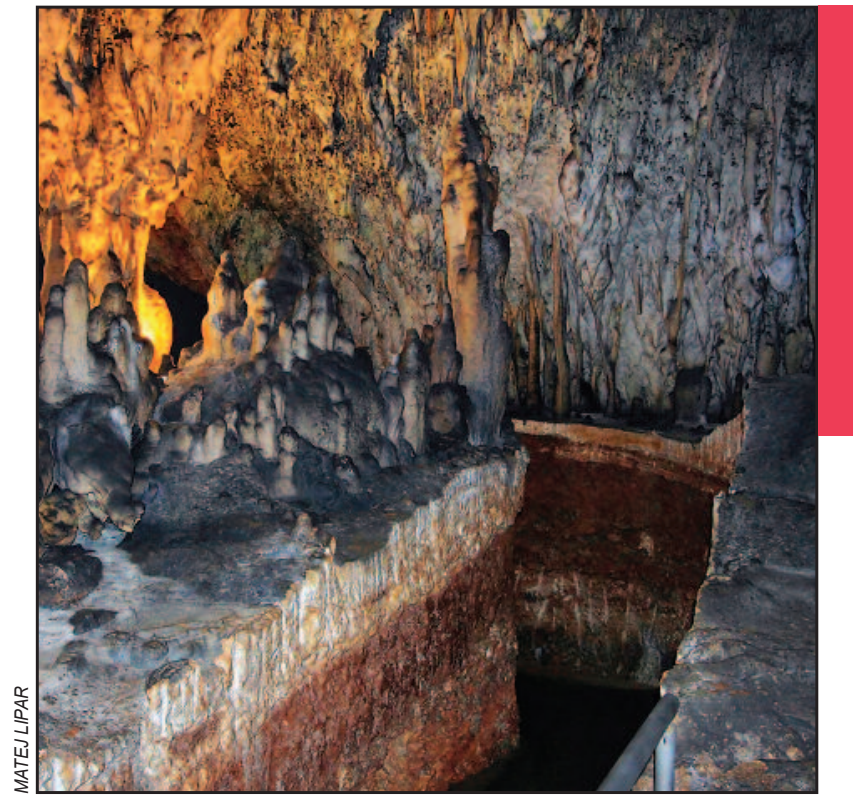

The trail cut into cave deposits. 
DOI: https://doi.org/10.3986/AGS.7059

UDC: $551.44: 552.5(497.4) \ll 628.62 \lll$

COBISS: 1.01

\title{
Chronology of heterogeneous deposits in the side entrance of Postojna Cave, Slovenia
}

\begin{abstract}
The development of the tourist trail in the side passage Rov Novih Podpisov of Postojna Cave in 2002 exposed an over four metres thick sedimentary succession characterised by horizontal flowstone layers intercalated between fine-grained fluvial sediments, and gravel deposits that record past environmental changes. The time of the flowstone deposition was determined by radiocarbon and uranium-thorium dating techniques. The results yielded three distinctive age groups of flowstone facies of $33 \mathrm{ka} \mathrm{BP}, 103 \mathrm{ka}$ BP and $153 \mathrm{ka}$ BP. These results also indicate that flowstone deposition has not been limited solely to periods of warm climate, which suggests that environmental conditions during glacial periods in south-western Slovenia supported flowstone deposition.
\end{abstract}

KEY WORDS: Geography, geoscience, geology, karst, stratigraphy, dating, ${ }^{14} \mathrm{C}$, U/Th

\section{Časovna interpretacija raznovrstnih sedimentov $\mathrm{v}$ stranskem vhodnem rovu Postojnske jame, Slovenija}

POVZETEK: Pri modernizaciji turistične poti v Rovu novih podpisov, ki je stranski rov Postojnske jame, leta 2002 je bilo v več kot štiri metre globokem vkopu odkrito zaporedje menjajočih se plasti sige, fluvialnih sedimentov in grušča. Te plasti so pomemben pokazatelj preteklih okoljskih sprememb. Starost sige med plastmi je bila določena z radioogljikovo in uran-torijevo metodo. Siga se je odlagala v treh obdobjih, in sicer okoli $33 \mathrm{ka} \mathrm{BP,} 103 \mathrm{ka}$ BP in $153 \mathrm{ka}$ BP. Odlaganje sige ni bilo omejeno zgolj na topla obdobja, ampak se je siga odlagala tudi v hladnejših obdobjih. Rezultati kažejo, da je bilo na območju jugozahodne Slovenije vsaj v nekaterih hladnih obdobjih Pleistocena podnebje primerno za rast sige.

KLJUČNE BESEDE: Geografija, geoznanost, geologija, kras, stratigrafija, datiranje, ${ }^{14} \mathrm{C}$, U/Th

\section{Mateja Ferk, Matej Lipar}

Research Centre of the Slovenian Academy of Sciences and Arts, Anton Melik Geographical Institute mateja.ferk@zrc-sazu.si,matej.lipar@zrc-sazu.si

\section{Andrej Šmuc}

University of Ljubljana, Faculty of Natural Sciences and Engineering, Department of Geology andrej.smuc@geo.ntf.uni-lj.si

\section{Russell N. Drysdale}

The University of Melbourne, School of Geography and Université de Savoie-Mont Blanc rnd@unimelb.edu.au

\section{Jian Zhao}

The University of Queensland, Faculty of Science, School of Earth and Environmental Sciences j.zhao@uq.edu.au

The paper was submitted for publication on October 25, 2018.

Uredništvo je prejelo prispevek 25. oktobra 2018. 


\section{Introduction}

Postojna Cave is a $24 \mathrm{~km}$ long system of underground passages with multiple entrances (Cave Register 2018, Figure 1). It is located in south-west Slovenia, which is famous for its high diversity (Perko, Hrvatin, and Ciglič 2015; Perko, Ciglič and Hrvatin 2017). Since 1819 the cave has been managed as a show cave (Shaw and Čuk 2015). During the last two centuries different parts of the cave were sequentially arranged and equipped for public access. It has a long tradition of cave exploration and scientific research (Valvasor 1689; Hohenwart 1830; Schmidl 1854; Perko 1910; Gams 1968; Gospodarič 1969; 1971; Ikeya, Miki and Gospodarič 1983; Šebela 1998; Šebela and Sasowsky 1999; Mihevc 2002; Stepišnik 2004; Šebela and Turk 2011; Ferk 2016; DomínguezVillar et al. 2018; Pipan et al. 2018). It is a ponor cave of the Pivka River in the contact karst area where the surface streams (e.g., Lekinka River) from impermeable Eocene flysch rock sink into the karstified Upper Cretaceous limestone (Buser, Grad and Pleničar 1967; Šebela 1998; Pleničar, Ogorelec and Novak 2009; Stepišnik 2017).

The cave passages were formed at two main levels. The lower, several meters wide passages, are in the epiphreatic zone and periodically flooded on a yearly basis. The walls and ceiling contain solutional rock features (e.g. scallops), whilst the floor is mostly covered by fluvial sediments (i.e. flysch gravel) (Gospodarič and Habič 1966). Passages on the higher level have diameters mostly around $10 \mathrm{~m}$ and are hydrologically inactive. However, they preserve remnants of solution (e.g., scallops) and numerous interchanging fluvial and chemogenic sediments that were deposited in changing conditions, revealing a hydrologically dynamic evolution during their speleogenesis. Cave sediments indicate repeated fluvial deposition and successive erosion (Gams 1966; Gospodarič 1976). Palaeomagnetic analyses show that the oldest sediments are up to $2.15 \mathrm{Ma}$ old, revealing that the cave system has evolved over a long period of time (Šebela and Sasowsky 1999; Zupan Hajna et al. 2008). The fluvial deposits and layers of flowstone close to the cave entrances are intersected by sequences of slope-derived gravel, remnants of Pleistocene large mammals and stone tools of Palaeolithic hunters (Rakovec 1954; Brodar 1966; 1969; Bavdek 2003).

About $50 \mathrm{~m}$ east of the main entrance to Postojna Cave is the entrance to one of its side passages called Rov Novih Podpisov that joins the main channel Stare Jame after about $150 \mathrm{~m}$. The passage belongs to the higher and hydrologically inactive level. The passage floor at the entrance is on the elevation of $530 \mathrm{~m}$ a.s.l. which is from 10 to $19 \mathrm{~m}$ above the present ponor of Pivka River (from 511 to $520 \mathrm{~m}$ a.s.l.) depending on the water level. The shallow cave passage, from 2 to $4 \mathrm{~m}$ high and in average $10 \mathrm{~m}$ wide, was equipped as a biospeleological laboratory in 1931. At present it operates as the Vivarium with a research facility and an exhibition section where basic concepts of karstology and speleobiology are presented to the visitors. Recent slope-derived gravel covering the entrance was removed during construction works in the 1930s. In 2002 the entrance part was modified to ease access to the Vivarium for tourists. An over four metres deep trench was cut into the floor exposing a flowstone covered sedimentary succession composed of various cave sediments.

Palaeomagnetic research on the exposed sediments showed only $\mathrm{N}$ polarized magnetisation corresponding to the Brunhes Chron indicating the sediment was deposited within the last $780 \mathrm{ka}$ (Zupan Hajna et al. 2008). Despite lacking any data of numerical dating the profile vas interpreted as »very young "Zupan Hajna et al. 2008, 176). Based on Mousterian artefacts found in a nearby cave channel also filled with various sediments (Brodar 1966; Bavdek 2003), the middle and upper part of the profile was interpreted to be less than $40 \mathrm{ka}$ old and the flowstone layer covering the profile to be of Holocene age (Mihevc and Zupan Hajna 2004; Gabrovšek and Mihevc 2009; Mihevc and Gabrovšek 2012). However, results of the first numerical dating of the uppermost flowstone revealed it was deposited $36 \mathrm{ka}$ BP (Ferk 2016) strongly implying the previous chronological interpretations of the profile were inaccurate.

The aim of the paper is to present results of two different dating techniques coupled with additional mineralogical and grain size analyses to provide the robust chronological timeline of the exposed heterogeneous deposits, which will be beneficial for further palaeoenvironmental studies.

\section{Methods}

The $4.16 \mathrm{~m}$ thick profile was recorded in resolution bed-to bed using standard sedimentological log in 1:10 scale. Six stratigraphic levels were identified (Figure 2). From the succession five flowstone samples were 
Mateja Ferk, Matej Lipar, Andrej Šmuc, Russell N. Drysdale, Jian Zhao, Chronology of heterogeneous deposits in the side ...

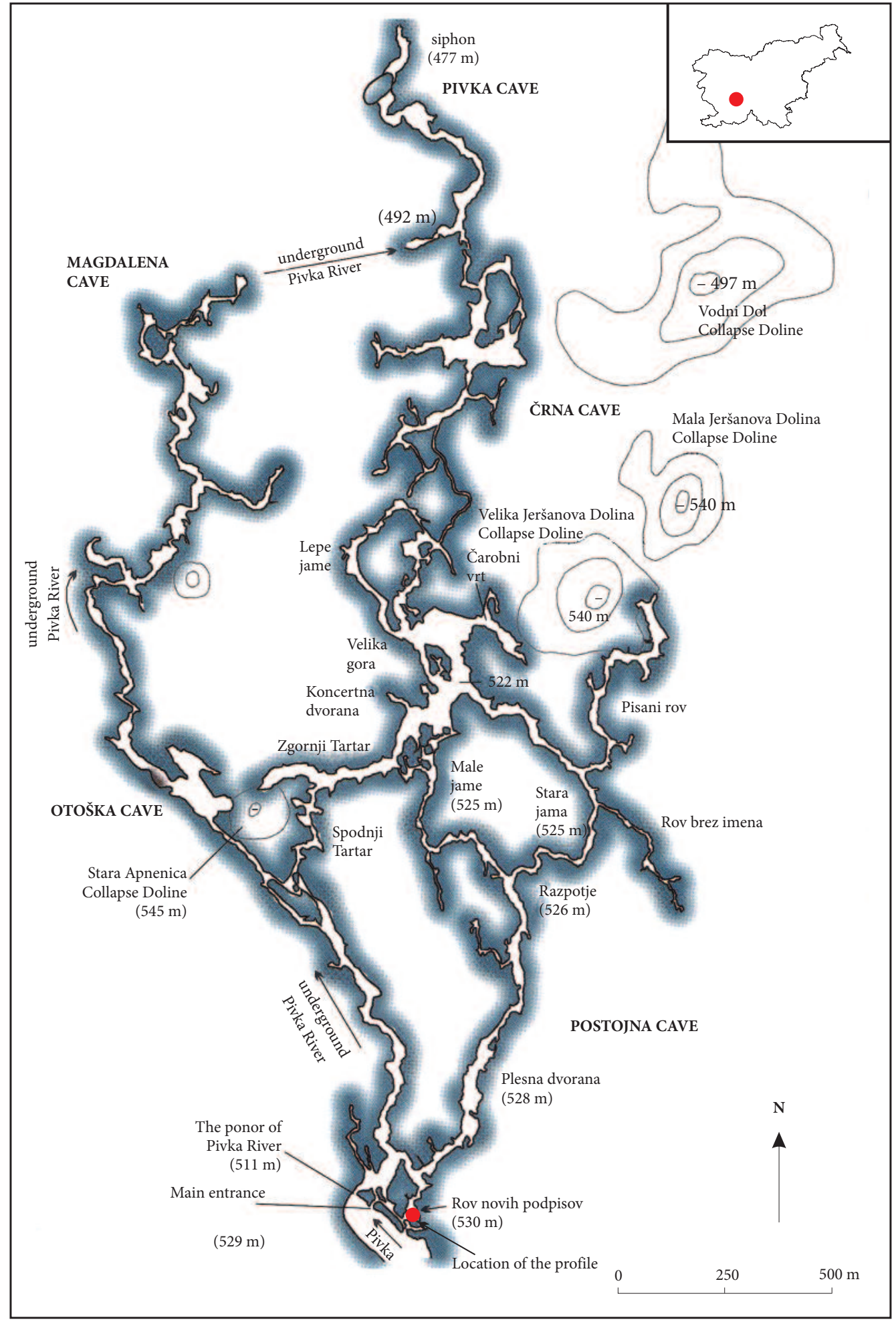


acquired for age and geochemical analysis and one fine-grained clastic sediment sample was collected for mineralogical and grain size analyses.

\subsection{Laboratory analyses for chemically precipitated sediment layers (flowstone)}

Two stratigraphically older samples of flowstone were dated by the uranium-thorium (U/Th) method at the University of Queensland (Brisbane, Australia). To assure that samples have enough U/Th for dating, they were first sampled to provide ICP-MS trace element data. Ages were corrected for non-radiogenic ${ }^{230} \mathrm{Th}$ incorporated at the time of deposition. Full details of the method are provided in Hellstrom (2003; 2006). Age errors are reported as $2 \sigma$ uncertainties.

In addition, the flowstone samples were analysed for both $\delta^{13} \mathrm{C}$ and $\delta^{18} \mathrm{O}$ isotopes at the stable isotope laboratory at the University of Melbourne (Australia), alongside with four samples of present-forming flowstone to compare the results for basic interpretation of climatic differences between the times of older flowstone deposition and present. Analyses were performed on $\mathrm{CO}_{2}$ produced by reaction of the sample with $100 \% \mathrm{H}_{3} \mathrm{PO}_{4}$ at $70^{\circ} \mathrm{C}$ using continuous-flow isotope ratio mass spectrometry (CF-IRMS), following the method previously described in Drysdale et al. (2009) and employing an AP2003 instrument. Results are reported using the standard $\delta$ notation (\%) relative to the VPDB scale. Based on the following working standards, the uncertainty was $0.05 \%$ for $\delta^{13} \mathrm{C}$ and $0.07 \%$ for $\delta^{18} \mathrm{O}$ based on the NEW 1 standard.

Three stratigraphically higher deposited samples of flowstone were dated by the radiocarbon technique at the Beta Analytic Laboratory in Miami, USA. All samples provided enough carbon for accurate measurements. The ages are reported as RCYBP (radiocarbon years before present (AD 1950)). The modern reference standard was $95 \%$ the ${ }^{14} \mathrm{C}$ activity of the National Institute of Standards and Technoloy (NIST) Oxallic Acid (SRM 4990C) and calculated using the Libby ${ }^{14} \mathrm{C}$ half-life (5568 years). The Conventional Radiocarbon Age represents the Measured Radiocarbon Age corrected for isotopic fractionation, calculated using the $\delta^{13} \mathrm{C}$ relative to the Vienna Peedee Belemnite (VPDB) scale. The Calendar Calibrated results are calculated from the Conventional Radiocarbon Age and listed as $2 \sigma$ calibrated results.

\subsection{Laboratory analyses for clastic sediment sample}

The qualitative and quantitative mineral composition of the stratigraphically highest and youngest loamy sediment (facies B, see chapter 3) was determined by X-ray powder diffraction (XRD) analysis, which, in turn, indicates the source of the sediment (Haldorsen et al. 1989; Stanley, Nil and Galili 1998). We used the Faculty of Natural Sciences and Engineering, University of Ljubljana (Slovenia) Philips PW3710 diffractometer equipped with a $\mathrm{Cu} \mathrm{Ka}$ radiation and a graphite monochromator, operating at $40 \mathrm{kV}$ and $30 \mathrm{~mA}$ in continual scan mode with a speed of $0.5^{\circ} / \mathrm{min}$ from $2^{\circ}$ to $70^{\circ} 2 \Theta$. The Rietveld Method was used for semiquantitative mineralogical analysis.

To determine the deposition dynamics of the same sediment the grain size analysis using a Malvern Mastersizer 2000 particle analyser at La Trobe University (Melbourne, Australia) was carried out; full details of the latter analytical procedure are provided in Sperazza, Moore and Hendrix (2004).

\section{Results and discussion}

The maximum thickness of the exposed profile is $416 \mathrm{~cm}$. We divided it into six stratigraphic levels of various horizontal facies (Figure 2). From bottom to top, these are:

- 416 to $370 \mathrm{~cm}$, subangular gravel mixed with fine-grained sediment (facies F);

- 370 to $210 \mathrm{~cm}$, very angular gravel mixed with fine-grained sediment and partly cemented with calcite (facies E);

- 210 to $190 \mathrm{~cm}$, white flowstone layers intercalated by two up to $1 \mathrm{~cm}$ thick black layers (facies D);

- 190 to $90 \mathrm{~cm}$, angular gravel mixed with fine-grained sediment containing bones in the lower part (facies C);

- 90 to $45 \mathrm{~cm}$, fine-grained sediment with indistinctive horizontal parallel lamination (facies B);

- 45 to $0 \mathrm{~cm}$, white flowstone layers intercalated by millimetre thin layers of fine-grained sediment towards the lowest part (facies A). 


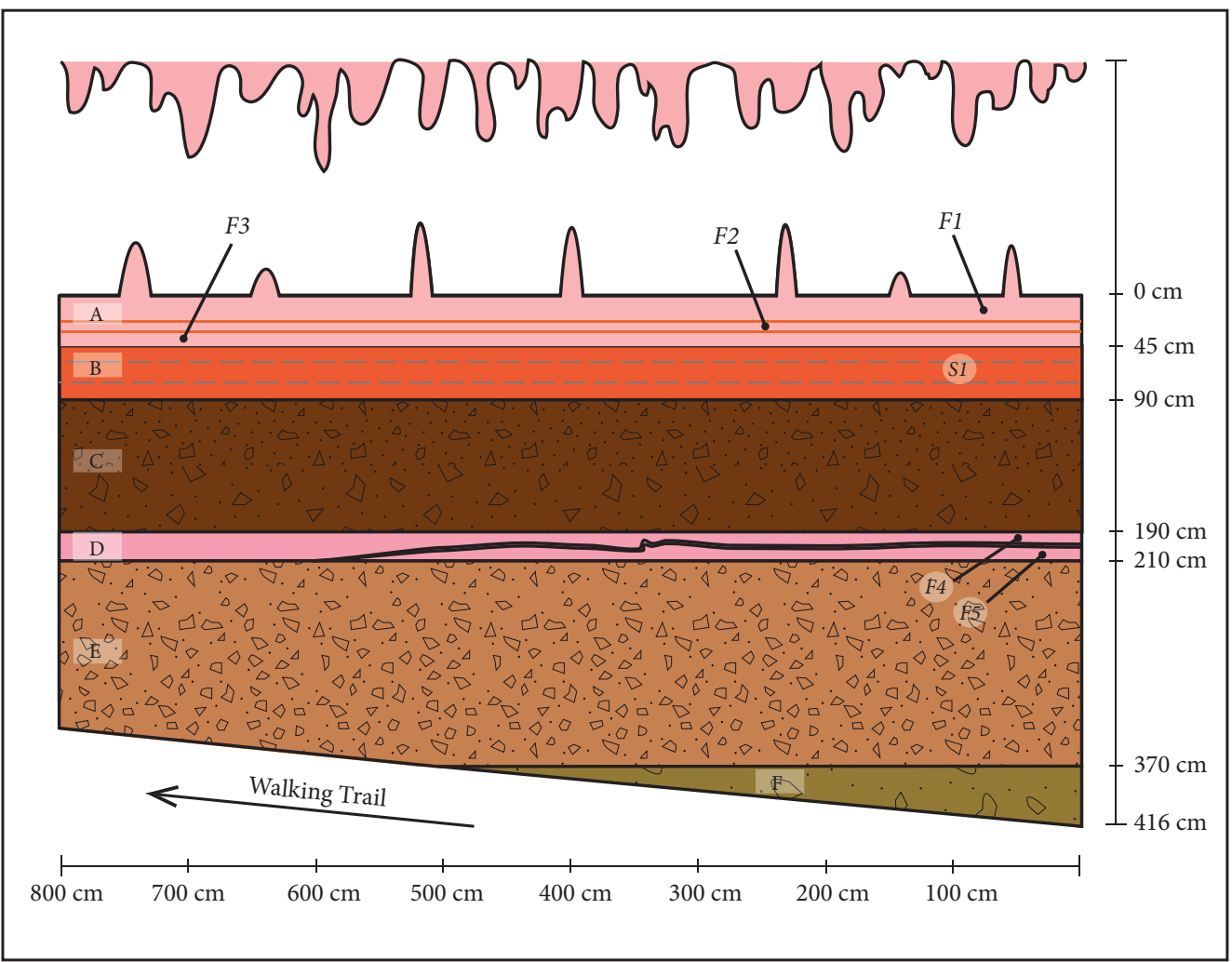

Figure 2: Stratigraphic levels of horizontal facies identified in the analysed sediment profile in the side passage Rov Novih Podpisov of Postojna Cave.

\subsection{Facies $\mathrm{F}$}

Facies $\mathrm{F}$ is the oldest recognised facies in the succession (Figure 2). The total thickness cannot be determined due to the limited exposure but is at least $46 \mathrm{~cm}$ thick. The facies consists of subangular limestone gravel with clast size mostly around $5-10 \mathrm{~cm}$ and some larger pieces with diameters up to $20 \mathrm{~cm}$. The gravel is poorly sorted and mixed with grey to yellow fine-grained sediments presumably originating from the flysch rocks in the Pivka Basin (Zupan Hajna et al. 2008). Mihevc and Zupan Hajna (2004) describe the facies F as the oldest sediment deposited in the cave by the Pivka River which was partly eroded away in the upper part.

\subsection{Facies E}

The facies $\mathrm{E}$ is $160 \mathrm{~cm}$ thick and is the thickest facies in the succession (Figure 2). It consists of very angular well sorted limestone gravel with clast size around $5 \mathrm{~cm}$. The gravel originates from the local limestone which builds cave walls and ceiling. It is partly cemented with calcite in the upper part. The amount of calcite cement decreases towards the lower part of the facies. The gravel is mixed with light brown finegrained sediment.

Mihevc and Zupan Hajna (2004) assumed the layer was deposited at the beginning of the last glacial period (Würm glaciation; Marine Isotope Stage (MIS) 5-2) in climate similar to the present one (Mihevc and Gabrovšek 2012) although no numerical datations were published. Results of the current study revealed an older age of the deposits, since the deposition of the facies E ended more than $150 \mathrm{ka} \mathrm{BP}$ (see chapter 3.3). 


\subsection{Facies D}

The facies $\mathrm{F}$ is covered by a $30 \mathrm{~cm}$ thick layer of white flowstone (facies D; Figure 2). The flowstone includes two up to $1 \mathrm{~cm}$ thick black layers that resemble charcoal. Two samples of flowstone from facies $\mathrm{D}$ were analysed; sample F4 was taken from the upper part of the facies, from above the black layer, and sample F5 was taken from the lower part of the facies, from beneath the black layer.

The results of the ICP-MS trace element data (Table 1) revealed that both samples have U/Th levels high enough for dating. The U/Th dating results yielded an age of $103.2 \mathrm{ka}$ (MIS 5c) for the stratigraphically younger flowstone (F4) and 153.1 ka (MIS 6) for the older flowstone (F5) (Table 2).

Table 1: ICP-MS trace element data for the flowstone of facies D. Concentration results in ppb or ng/g. Note: ${ }^{6} \mathrm{He}$ (i.e. enriched ${ }^{6} \mathrm{~L}$ ), ${ }^{61} \mathrm{Ni},{ }^{103} \mathrm{Rh},{ }^{115} \mathrm{n}$, ${ }^{187} \mathrm{Re}$ and ${ }^{235} \mathrm{~Np}$ (i.e. enriched ${ }^{235} \mathrm{U}$ ) are internal standards added to the sample solutions.

\begin{tabular}{lcccccccc}
\hline Sample & $F 4$ & $F 5$ & & $F 4$ & $F 5$ & & $F 4$ & $F 5$ \\
\hline${ }^{6} \mathrm{He}$ & 0 & 0 & ${ }^{86} \mathrm{Sr}$ & 24994 & 30598 & ${ }^{165} \mathrm{Ho}$ & 2.8 & 2.8 \\
${ }^{7} \mathrm{Li}$ & 72.2 & 27.7 & ${ }^{89} \mathrm{Y}$ & 106.7 & 108.8 & ${ }^{166} \mathrm{Er}$ & 7.7 & 7.8 \\
${ }^{9} \mathrm{Be}$ & 28.2 & 12.8 & ${ }^{90} \mathrm{Zr}$ & 96.2 & 70.4 & ${ }^{169} \mathrm{Tm}$ & 1.1 & 1.1 \\
${ }^{25} \mathrm{Mg}$ & 102191 & 104147 & ${ }^{93} \mathrm{Nb}$ & 9 & 4.8 & ${ }^{172} \mathrm{Yb}$ & 6.5 & 6.7 \\
${ }^{31} \mathrm{p}$ & 341172 & 162150 & ${ }^{98} \mathrm{Mo}$ & 4.3 & 2.1 & ${ }^{175} \mathrm{Lu}$ & 0.9 & 0.9 \\
${ }^{43} \mathrm{Ca}$ & 427280107 & 411705358 & ${ }^{103} \mathrm{Rh}$ & 0 & 0 & $178 \mathrm{Hf}$ & 1.6 & 1.2 \\
${ }^{45} \mathrm{Sc}$ & 112.9 & 111.8 & ${ }^{111} \mathrm{Cd}$ & 35 & 47.8 & ${ }^{181} \mathrm{Ta}$ & -0.4 & -0.5 \\
${ }^{49} \mathrm{Ti}$ & 1702.1 & 1291.9 & ${ }^{115} \mathrm{I}$ & 0 & 0 & ${ }^{184} \mathrm{~W}$ & 4.7 & 4 \\
${ }^{51} \mathrm{~V}$ & 326.8 & 236.1 & ${ }^{120} \mathrm{Sn}$ & 2.3 & -3.9 & ${ }^{187} \mathrm{Re}$ & 0 & 0 \\
${ }^{53} \mathrm{Cr}$ & 265.1 & 340.9 & ${ }^{121} \mathrm{Sb}$ & 2.2 & 2.2 & ${ }^{202} \mathrm{Hg}$ & 46 & 45.7 \\
${ }^{55} \mathrm{Mn}$ & 1097.7 & 1525.3 & ${ }^{133} \mathrm{CS}$ & 17 & 9.3 & ${ }^{205} \mathrm{Tl}$ & 12.5 & 12.7 \\
${ }^{57} \mathrm{Fe}$ & 807828 & 776202 & ${ }^{137} \mathrm{Ba}$ & 2569.5 & 12116 & ${ }^{206} \mathrm{~Pb}$ & 83.8 & 69.3 \\
${ }^{59} \mathrm{Co}$ & 256.4 & 312.3 & ${ }^{139} \mathrm{La}$ & 84.2 & 79.5 & ${ }^{207} \mathrm{~Pb}$ & 76.1 & 62.6 \\
${ }^{60} \mathrm{Ni}$ & 42550 & 3658 & ${ }^{140} \mathrm{Ce}$ & 167.5 & 134.8 & ${ }^{208} \mathrm{~Pb}$ & 79.1 & 64 \\
${ }^{61} \mathrm{Ni}$ & 0 & 0 & ${ }^{141} \mathrm{Pr}$ & 22.3 & 19.9 & ${ }^{209} \mathrm{Bi}$ & 2.3 & 1.4 \\
${ }^{65} \mathrm{Cu}$ & 687.3 & 411.9 & ${ }^{146} \mathrm{Nd}$ & 84.7 & 82.1 & ${ }^{220} \mathrm{Bkg}$ & 0 & 0 \\
${ }^{66} \mathrm{Zn}$ & 1170.7 & 550 & ${ }^{149} \mathrm{Sm}$ & 18.7 & 17.8 & ${ }^{232} \mathrm{Th}$ & 13 & 9.7 \\
${ }^{69} \mathrm{Ga}$ & 15.2 & -57.8 & ${ }^{151} \mathrm{Eu}$ & 4.1 & 4.2 & ${ }^{235} \mathrm{~Np}$ & 0 & 0 \\
${ }^{71} \mathrm{Ga}$ & 26.4 & 14.8 & ${ }^{159} \mathrm{~Tb}$ & 2.8 & 2.4 & ${ }^{238} \mathrm{U}$ & 362.4 & 215.3 \\
${ }^{74} \mathrm{Ge}$ & 1.6 & 0.2 & ${ }^{160} \mathrm{Gd}$ & 17.8 & 16.5 & $\mathrm{U} / \mathrm{Th}$ & 28.0 & 22.2 \\
${ }^{85} \mathrm{Rb}$ & 187.5 & 100.2 & ${ }^{161} \mathrm{Dy}$ & 14.8 & 12.8 & & & \\
\hline
\end{tabular}

Table 2: U-Th isotope data for the flowstone of facies D. Two laboratory standards included: YB-1 is an ANU speleothem standard with an age of $30.2 \pm 0.6 \mathrm{ka}$. SRM-960 U is a metal standard manufactured during the World War II ( 1936).

\begin{tabular}{lcccc}
\hline Sample & $F 4$ & $F 5$ & SRM-960 standard & YB-1 speleothem std \\
\hline Sample wt. (g) & 0.103 & 0.103 & 0.1057 & 0.10214 \\
U (ppm) & 0.35038 & 0.23732 & 5.53963 & 0.12525 \\
\pm 20 & 0.00015 & 0.00010 & 0.0046 & 0.00004 \\
\hline $232 \mathrm{Th}(\mathrm{ppb})$ & 51.442 & 46.151 & 0.008 & 0.486 \\
$\pm 2 \sigma$ & 0.083 & 0.062 & 0.000 & 0.001 \\
$(230 \mathrm{Th} / 232 \mathrm{Th})$ & 13.091 & 12.044 & 1484.971 & 339.829 \\
\pm 20 & 0.039 & 0.034 & 28.251 & 1.229 \\
$(230 \mathrm{Th} / 238 \mathrm{U})$ & 0.6334 & 0.7719 & 0.0007 & 0.4343 \\
\pm 20 & 0.0016 & 0.0020 & 0.00001 & 0.0015 \\
$(234 \mathrm{U} /$ 238U) & 1.0095 & 1.0055 & 0.9636 & 1.7492 \\
\pm 20 & 0.0011 & 0.0009 & 0.0007 & 0.0013 \\
Uncorr. Age (ka) & 107.59 & 159.0 & 0.0805 & 30.53 \\
\pm 20 & 0.51 & 1.0 & 0.0009 & 0.12 \\
Corr. Age (ka) & 103.2 & 153.1 & 0.0805 & 30.46 \\
\pm 20 & 2.3 & 3.1 & 0.0009 & 0.12 \\
Corr. Initial (234U/238U) & 1.0132 & 1.0090 & 0.9636 & 1.8174 \\
\pm 20 & 0.0015 & 0.0015 & 0.0007 & 0.0014 \\
\hline
\end{tabular}


The up to $1 \mathrm{~cm}$ thick black layers resembling charcoal deposits in the middle part of the flowstone has not been examined. According to the presence of a Palaeolithic site in the close vicinity where artefacts of Mousterian stone tools were discovered (Brodar 1966) it is likely the layer is a cultural deposit. Based on the measured ages of the flowstone underlying and covering the black layer it should be attributed to the presence of Neanderthals, which is in accordance with the Mousterian stone tools found nearby (Brodar 1966; Bavdek 2003).

According to the general palaeoclimatic curve for that time frame (Friedrich et al. 2016), the flowstone was deposited during the MIS 6 glacial period with generally colder temperatures and the MIS $5 \mathrm{c}$ interstadial with generally warmer temperatures. In addition, the flowstone layers have heavier oxygen isotopic values $(-6.45 \%$ o (F4) and $-6.20 \%$ o (F5)) than the present-forming flowstone ( -6.83$)$, which may reflect a reduced plant activity and thus lower levels of soil $\mathrm{CO}_{2}$ production, or a higher proportion of plants adopted to the climate with less effective rainfall during the time of flowstone deposition (103.2 ka and $153.1 \mathrm{ka}$ BP; Figure 3). This could be especially valid for the MIS 6 glacial period (and the heaviest value of the F5 sample) when global water circulation was reduced due to lower evaporation.

\subsection{Facies $\mathrm{C}$}

Facies $\mathrm{C}$ is a $1 \mathrm{~m}$ thick layer of moderately sorted gravel composed of angular limestone clasts. In the lowermost part the clasts are up to $10 \mathrm{~cm}$ large and animal bones are present between them, while the clasts are smaller (up to $5 \mathrm{~cm}$ ) in the middle and upper part of the facies. The gravel is mixed with brown finegrained sediment. The clasts are composed of the same rock as the cave walls and ceiling. Mihevc and Gabrovšek (2012) interpreted the gravel slided from the entrance deeper into the cave by cryoturbation. Based on archaeological findings of Mousterian stone tools at the nearby Palaeolithic site, few tens of metres away (Brodar 1966), Mihevc and Zupan Hajna (2004) assumed the facies C was deposited between 40 and $20 \mathrm{ka} \mathrm{BP}$ and during the Last Glacial Maximum. However, results of the numerical dating methods show the time of gravel deposition in the cave is constrained by the lower lying $103.2 \mathrm{ka}$ old horizontal layer of flowstone (facies D) and the $36.8 \mathrm{ka}$ old flowstone toping the profile (facies A). Therefore, the facies $\mathrm{C}$ is older than previously believed and was deposited between MIS $5 \mathrm{c}$ and MIS 3 . The gravel production may have intensified at the transition between MIS $5 \mathrm{a}$ and the glacial maximum during MIS 4 when the general average temperatures were lower than the present one (Friedrich et al. 2016).

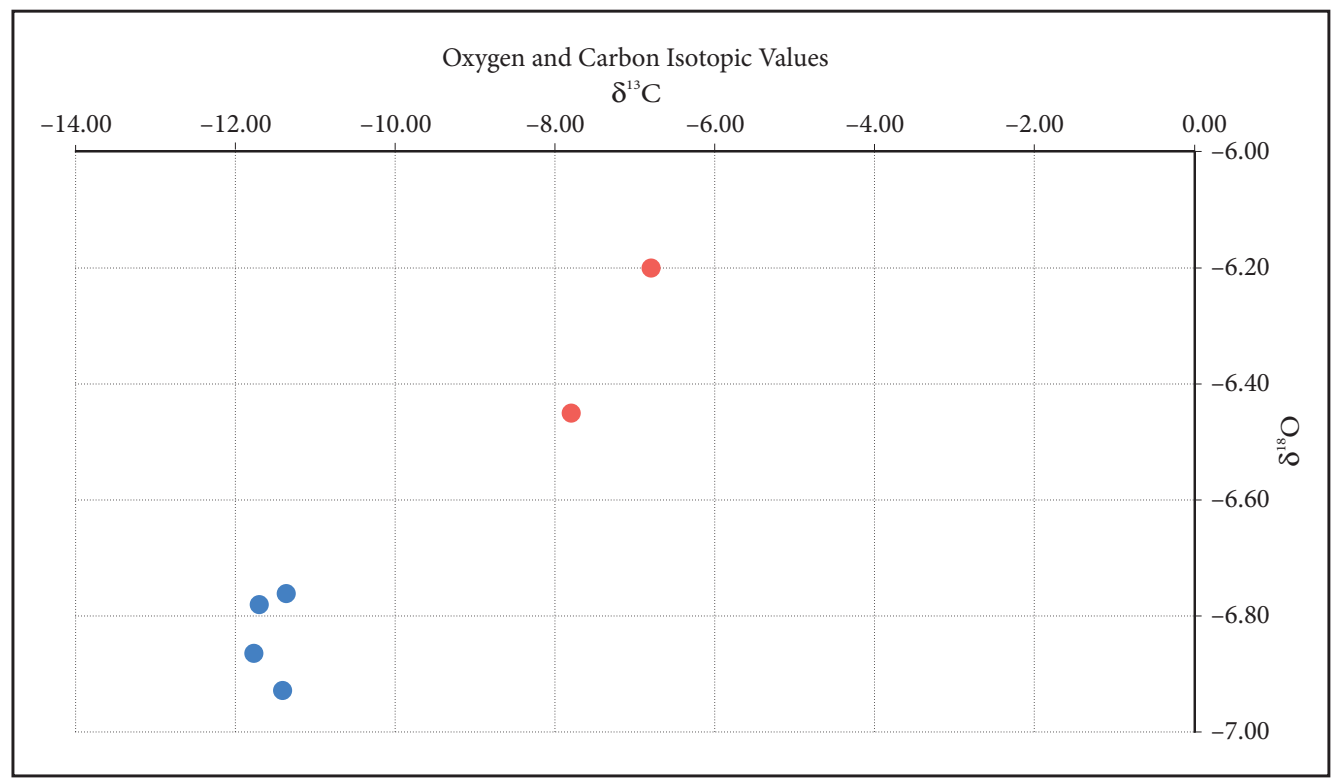

Figure 3: Diagram of oxygen and carbon isotope values of the flowstone (facies D). Orange colour: flowstone samples F4 and F5; blue colour: present-day samples of flowstone. 


\subsection{Facies B}

Facies $\mathrm{B}$ is a $45 \mathrm{~cm}$ thick layer of homogenous red fine-grained sediment with partially preserved horizontal and parallel lamination which was sampled for mineral and grain size analyses. The X-ray powder diffraction (XRD) analysis showed that the sediment consists of quartz (47\%), muscovite/illite (24\%), chlorite (18\%), K-Na feldspar (7\%) and kaolinite (4\%) (Ferk 2016). Based on the mineral composition the provenance of this sediments are flysch rocks (Orehek 1970) present in the Pivka River catchment (Buser, Grad and Pleničar 1976; Pleničar, Ogorelec and Novak 2009). The grain size analysis showed the sediment is silt loam according to the Soil Bulk Density Calculator (Wentworth 1922; Plaster 1992), consisting of $68.61 \%$ silt, $21.9 \%$ clay, and $9.49 \%$ sand (Table 3; Figure 4 ).

Table 3: Grain size characteristics of the facies B sediment (sample S1).

\begin{tabular}{|c|c|c|c|c|}
\hline \multirow[t]{2}{*}{ Grain size (mm) } & \multicolumn{2}{|c|}{ Classification } & \multicolumn{2}{|c|}{ Percentage (\%) } \\
\hline & Major & Minor & & \\
\hline $2-1$ & \multirow[t]{5}{*}{ Sand } & Very coarse sand & 0.59 & \multirow[t]{5}{*}{9.49} \\
\hline $1-0.5$ & & Coarse sand & 2.21 & \\
\hline $0.5-0.25$ & & Medium sand & 2.18 & \\
\hline $0.25-0.125$ & & Fine sand & 1.27 & \\
\hline $0.125-0.062$ & & Very fine sand & 3.24 & \\
\hline $0.062-0.031$ & \multirow[t]{4}{*}{ Silt } & Very coarse silt & 10.15 & \multirow[t]{4}{*}{68.61} \\
\hline $0.031-0.016$ & & Coarse silt & 18.43 & \\
\hline $0.016-0.008$ & & Fine silt & 21.07 & \\
\hline $0.008-0.004$ & & Very fine silt & 18.96 & \\
\hline$<0.004$ & Clay & Clay & 21.9 & 21.9 \\
\hline
\end{tabular}

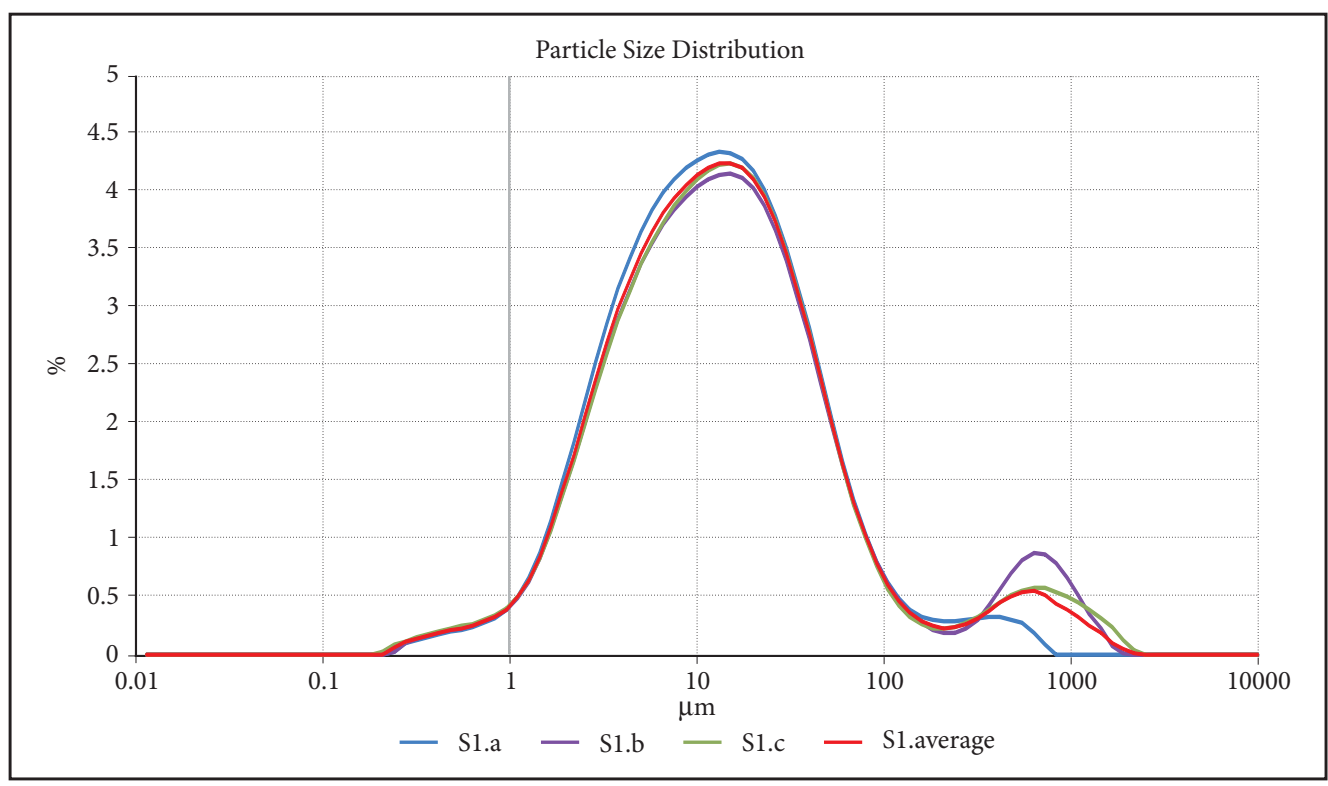

Figure 4: Grain size characteristics of the facies B sediment (sample S1). 
Supposedly, these sediments were washed into the cave from the Pivka Basin during episodic flooding and sedimentation from suspension in a standing or slow-moving water as suggested by parallel horizontal lamination and silt loam texture of the sediment (cf. Farrant and Smart 2011; Ferk 2016). Considering that the laminas are less than $1 \mathrm{~mm}$ thick, the $45 \mathrm{~cm}$ thickness of the sediment would suggest a long time-scale of periodical flooding and not a single extreme event. However, laminated silt loam deposits can derive from aeolian material redeposited by overland flow (Mücher and De Ploey 1984) which is in accordance with Zupan Hajna et al. (2008) who suggested that the sediment of facies B was washed into the cave from the surface. Nevertheless, the age of the flowstone (facies A) above the silt loam sediment shows that the sedimentation of facies B ceased around $36.8 \mathrm{ka} \mathrm{BP}$.

\subsection{Facies A}

The top layer of the profile, facies $\mathrm{A}$, is a $45 \mathrm{~cm}$ thick white flowstone. In the lower half the flowstone is intercalated with thin layers of red fine-grained sediment. Three flowstone samples from facies A were dated using radiocarbon technique (Table 4). The micro location of the samples within the flowstone was chosen based on their stratigraphic location (Figure 2): sample F1 was taken from the top of the facies A, sample F2 was taken from the middle of the facies A underlying an up to $5 \mathrm{~cm}$ thick layer of fine-grained sediment, and sample F3 was taken from the lowest part of the facies underlying an up to $1 \mathrm{~cm}$ thick layer of intercalated fine-grained sediment. The calibrated radiocarbon ages of flowstone F1, F2 and F3 yielded ages of $33.2 \mathrm{ka}, 34.9 \mathrm{ka}$ and $36.8 \mathrm{ka} \mathrm{BP}$, respectively. Their accordance with the stratigraphical position strengthens the reliability of the results and suggests the deposition of the facies A between 33.2 and $36.8 \mathrm{ka}$ (Ferk 2016). The age of the facies A is older than previously thought when it was linked to the Holocene (Mihevc and Zupan Hajna 2004; Zupan Hajna et al. 2008).

The deposition of flowstone occurred during MIS 3 which is characterised by high variation of average temperature amplitudes, although the stage in general is part of the last glacial period (Lisiecki and Raymo 2005). During the MIS 3 the temperatures were globally slightly higher than during the MIS 2 and MIS 4 periods. The cave entrance at that time must have been blocked as flowstone deposition requires absence of frost weathering. This is strongly indicated also by the absence of broken speleothems or frost weathering affected speleothems during the Last Glacial Maximum (e.g. MIS 2). The end of flowstone deposition towards the final stage of MIS 3 marks the beginning of a still ongoing hiatus in deposition at the location of the analysed profile.

The carbon isotopic values of the flowstone are heavier than the present values (see Section 3.3) and suggest a reduced plant activity compared to a modern vegetation above the cave or a higher proportion of plants more adapted to drought (Gillies 2011), which could be a result of colder climate with less effective precipitation.

Table 4: Results of radiocarbon dating of the topmost flowstone (facies A).

\begin{tabular}{lccccccc}
\hline Sample & $\begin{array}{c}\text { Measured } \\
\text { Radiocarbon } \\
\text { Age (BP) }\end{array}$ & \pm 1RSD & $\begin{array}{c}\text { Conventional } \\
\text { Radiocarbon } \\
\text { Age (BP) }\end{array}$ & \pm IRSD & $\begin{array}{c}\text { 13C } \\
(\%) \text { PDB })\end{array}$ & $\begin{array}{c}\text { Calibrated } \\
\text { Radiocarbon } \\
\text { Age (BP) }\end{array}$ & \pm 20 \\
\hline F1 & 28410 & 140 & 28720 & 140 & -5.9 & 33165 & 275 \\
F2 & 30060 & 160 & 30330 & 160 & -8.4 & 34860 & 180 \\
F3 & 32080 & 180 & 32360 & 180 & -7.8 & 36800 & 240 \\
\hline
\end{tabular}

\section{Conclusion}

Construction works for touristic purposes in the Postojna Cave led to the exposure of an over 4 metres deep sedimentary succession composed of various cave sediments in the side passage Rov Novih Podpisov of the Postojna Cave. Six horizontal stratigraphic levels of depositional facies were identified (bottom to top); subangular gravel (facies F), very angular gravel (facies E), flowstone (facies D), angular gravel (facies C), red silt loam (facies B), and flowstone (facies A). 


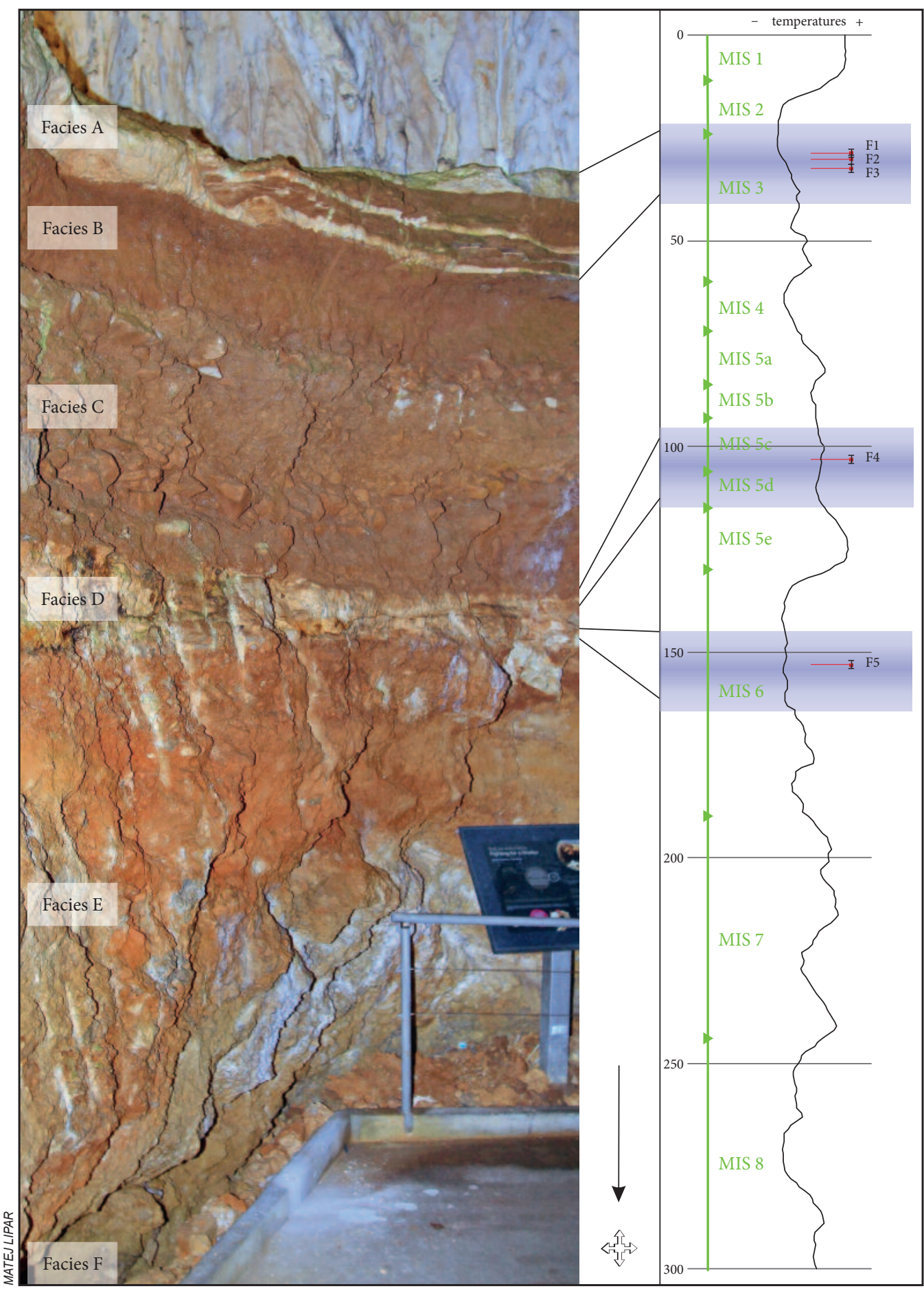

Figure 5: The profile of deposits at the side entrance of the Postojna Cave with the timeline of sediment deposition. The temperature curve is based on data by Friedrich et al. (2016). 
Flowstone from two stratigraphic levels (facies A and D) was collected for radiocarbon (3 samples) and uranium-thorium (2 samples) dating, respectively. The dating results show the deposits are older than previously thought. The stratigraphically higher and younger flowstone was deposited in the second half of MIS 3 (33,2-36,8 ka BP), and the stratigraphically lower flowstone was deposited in the second half of MIS 6 $(153,1 \mathrm{ka} \mathrm{BP})$ and in MIS 5c (103,2 ka BP). The numerical dates of the flowstone age show its deposition during periods of low average temperatures. Consequently, we argue that despite lower temperatures in these periods the amount of precipitation was probably lower, but still sufficient to allow flowstone deposition.

During MIS 6 and MIS $5 c$ the flowstone deposition was probably occasionally interrupted which is indicated by two distinctive up to $1 \mathrm{~cm}$ thick black layers resembling charcoal, stretching throughout the side passage. The black layers could be a cultural deposit attributed to the Neanderthal activities and related to the nearby Palaeolithic site where Mousterian stone tools were found.

The dated facies of flowstone are separated by a $1 \mathrm{~m}$ thick layer of gravel (facies $\mathrm{C}$ ) and a $45 \mathrm{~cm}$ thick layer of red silt loam (facies B). The silt loam was sampled for mineral and grainsize analyses, proving the sediments origin in flysch rocks from where it was transported into the cave and deposited whether from calm water during floods or overland flow redeposition of aeolian sediment. Both facies between the flowstone layers were deposited between MIS $5 \mathrm{c}$ and MIS 3.

Based on the flowstone age, the stratigraphically lowermost layers of gravel (facies F and $\mathrm{E}$ ) were deposited earlier than $153.1 \mathrm{ka}$ BP. Especially the lowermost subangular gravel (facies F) could reach a significant age, since the upper boundary of the facies shows traces of an erosion phase during which at least some of the gravel was removed before the next depositional phase of gravel deposition begun (facies E).

ACKNOWLEDGEMENT: We thank Postojnska jama, d. d. and the Ministry of Environment and Spatial Planning of Slovenia for the permissions to access the caves and to collect samples. The research was financially supported by the Slovenian Research Agency research core funding Geography of Slovenia (P6-0101), and the European Regional Development Fund: European Union \& Republic of Slovenia, Ministry of Education, Science and Sport (research programme OP20.01261).

\section{References}

Bavdek, A. 2003: Arheološki nadzor v Postojnski jami. Naše jame 45.

Brodar, S. 1966: Pleistocenski sediment in paleolitska najdišča v Postojnski jami. Acta Carsologica 4.

Brodar, S. 1969: Latest Palaeolithic discoveries in the Postojna Caves. Acta Archaeologica 20.

Buser, S., Grad, K., Pleničar, M. 1967: Osnovna geološka karta SFRJ 1:100.000, list Postojna. Savezni geološki zavod. Beograd.

Cave Register 2018. Speleological Association of Slovenia. Ljubljana.

Domínguez-Villar, D., Lojen, S., Krklec, K., Kozdon, R., Edwards, R. L., Cheng, H. 2018: Ion microprobe $\delta 18 \mathrm{O}$ analyses to calibrate slow growth rate speleothem records with regional $\delta 18 \mathrm{O}$ records of precipitation. Earth and Planetary Science Letters 482. DOI: https://doi.org/10.1016/j.epsl.2017.11.012

Drysdale, R. N., Hellstrom, J. C., Zanchetta, G., Fallick, A. E., Sánchez Goñi, M. F., Couchoud, I., McDonald, J., Maas, R., Lohmann, G., Isola, I. 2009: Evidence for obliquity forcing of glacial termination II. Science 325-5947. DOI: https://doi.org/10.1126/science.1170371

Farrant, A. R., Smart, P. L. 2011: Role of sediment in speleogenesis; sedimentation and paragenesis. Geomorphology 134, 1-2. DOI: https://doi.org/10.1016/j.geomorph.2011.06.006

Ferk, M. 2016. Paleopoplave v porečju kraške Ljubljanice. Geografija Slovenije 33. Ljubljana.

Friedrich, T., Timmermann, A., Tigchelaar, M., Timm, O. E., Ganopolski, A. 2016: Nonlinear climate sensitivity and its implications for future greenhouse warming. Science Advances 2-11. DOI: https://doi.org/10.1126/ sciadv. 1501923

Gabrovšek, F., Mihevc, A. 2009: Cave Climate: Guide-booklet for the excursions and abstracts of presentations at the 17th International Karstological School »Classical Karst«. Postojna.

Gams, I. 1966: K hidrologiji ozemlja med Postojnskim, Planinskim in Cerkniškim poljem. Acta Carsologica 4.

Gams, I. 1968: Prispevek k vprašanju starosti Postojnske jame. Naše jame 9.

Gillies, S. L. 2011: CO2 levels and Plants. What's So Wrong with a Greenhouse? Biology on the Cutting Edge: Concepts, Issues, and Canadian Research around the Globe. Canada. 
Gospodarič, R. 1969: Speleološki procesi v Postojnski jami iz mlajšega pleistocena. Naše jame 10.

Gospodarič, R. 1971: Prvi podatki o absolutni starosti sige v Postojnski jami na podlagi 14C. Naše jame 13. Gospodarič, R. 1976: Razvoj jam med Pivško kotlino in Planinskim poljem v kvartarju. Acta Carsologica 7. Gospodarič, R., Habič, P. 1966: Črni potok in Lekinka v sistemu podzemeljskega odtoka iz Pivške kotline. Naše jame 8.

Haldorsen, S., Jorensen, P., Rappol, M., Riezebos, P. A. 1989: Composition and source of the clay-sized fraction of Saalian till in the Netherlands. Boreas 18-2. DOI: https://doi.org/10.1111/j.1502-3885.1989.tb00377.x

Hellstrom, J. 2003: Rapid and accurate U/Th dating using parallel ion-counting multi-collector ICP-MS. Journal of Analytical Atomic Spectrometry 11. DOI: https://doi.org/10.1039/B308781F

Hellstrom, J. 2006: U-Th dating of speleothems with high initial 230Th using stratigraphical constraint. Quaternary Geochronology 1-4. DOI: https://doi.org/10.1016/j.quageo.2007.01.004

Hohenwart, F. 1830: Wegweiser für die Wanderer in der berühmten Adelsberger und Kronprinz Ferdinands-Grotte bey Adelsberg in Krain. Laibach.

Ikeya, M., Miki, T., Gospodarič, R. 1983: ESR Dating of Postojna Cave Stalactite. Acta carsologica 11.

Lisiecki, L. E., Raymo, M. E. 2005: A Pliocene-Pleistocene stack of 57 globally distributed benthic $\delta 18 \mathrm{O}$ records. Paleoceanography 20. DOI: https://doi.org/10.1029/2004PA001071

Mihevc, A. 2002: U-Th datation of the collapse processes on Velika Gora. Evolution of karst: from prekarst to cessation: programme and guide booklet for the excursions. Postojna.

Mihevc, A., Gabrovšek, F. 2012: Karst forms and processes: Guide-booklet for the excursions and abstracts of presentations at the 20th International Karstological School »Classical Karst«. Postojna.

Mihevc, A., Zupan Hajna, N. (eds.) 2004: Dating of Cave Sediments: Gu - guide-booklet for the excursions and abstracts of presentations at the 12th International Karstological School »Classical Karst«. Postojna.

Mücher, H. J., De Ploey, J. 1984: Formation of afterflow silt loam deposits and structural modification due to drying under warm conditions: an experimental and micromorphological approach. Earth Surface Processes and Landforms 9. DOI: https://doi.org/10.1002/esp.3290090606

Orehek, S. 1970: Eocenski fliš Slovenije: II. faza - Pivška kotlina in Brkini. Ljubljana.

Perko, D., Hrvatin M., Ciglič, R. 2015: A methodology for natural landscape typification of Slovenia. Acta geographica Slovenica 55-2. DOI: https://doi.org/10.3986/AGS.1938

Perko, D., Ciglič, R., Hrvatin, M. 2017: Determination of landscape hotspots of Slovenia. Acta geographica Slovenica 57-1. DOI: http://dx.doi.org/10.3986/AGS. 4618

Perko, G. A. 1910: Die Adelsberger Grotte in Wort und Bild. Adelsberg.

Pipan, T., Petrič, M., Šebela, S., Culver, D. C. 2018: Analyzing climate change and surface-subsurface interactions using the Postojna Planina Cave System (Slovenia) as a model system. Regional Environmental Change 19-2. DOI: https://doi.org/10.1007/s10113-018-1349-z

Plaster, E. J. 1992: Soil Science and Management. New York.

Pleničar, M., Ogorelec, B., Novak, M. 2009: Geologija Slovenije/The Geology of Slovenia. Ljubljana.

Rakovec, I. 1954: Povodnji konj iz Pivške kotline. Razprave IV. razreda SAZU 2.

Schmidl, A. 1854: Die Grotten und Höhlen von Adelsberg, Lueg, Planina und Laas. Wien.

Shaw, T., Čuk, A. 2015: Slovene Karst and Caves in the Past. Ljubljana.

Sperazza, M., Moore, J. N., Hendrix, M. S. 2004: High-resolution particle size analysis of naturally occurring very fine-grained sediment through laser diffractometry. Journal of Sedimentary Research 74-5. DOI: https://doi.org/10.1306/031104740736

Stanley, D. J., Nir, Y., Galili, E. 1998: Clay mineral distributions to interpret Nile cell provenance and dispersal: III. Offshore margin between Nile delta and northern Israel. Journal of Coastal Research 14-1.

Stepišnik, U. 2004: The origin of sediments inside collapse dolines of Postojna karst (Slovenia). Acta Carsologica 33-1. DOI: https://doi.org/10.3986/ac.v33i1.326

Stepišnik, U. 2017: Dinarski kras: plitvi kras Zgornje Pivke. E-GeograFF 10. Ljubljana.

Šebela, S. 1998: Tektonska zgradba sistema Postojnskih jam. Ljubljana.

Šebela, S., Turk, J. 2011: Air temperature characteristics of the Postojna and Predjama cave systems. Acta geographica Slovenica 51-1. DOI: 10.3986/AGS51102

Šebela, S., Sasowsky, I. D. 1999: Age and magnetism of cave sediments from Postojnska jama cave system and Planinska jama cave, Slovenia. Acta Carsologica 28-2. DOI: https://doi.org/10.3986/ac.v28i2.498

Valvasor, J. W. 1689: Die Ehre dess Hertzogthums Crain. Laybach. 
Wentworth, C. K. 1922: A scale of grade and class terms for clastic sediments. Journal of Geology 30-5.

Zupan Hajna, N., Pruner, P., Mihevc, A., Bosák, P. 2008: Cave sediments from the Postojnska-Planinska cave system (Slovenia): Evidence of multi-phase evolution in epiphreatic zone. Acta Carsologica 37-1. DOI: https://doi.org/10.3986/ac.v37i1.160 